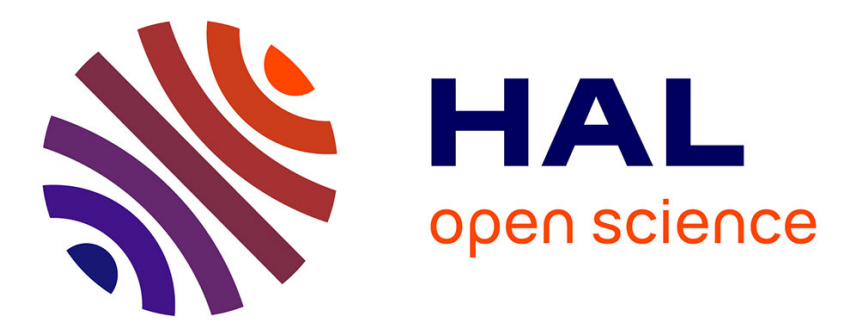

\title{
Structural and spectral studies of thiosemicarbazones derived from 3-furaldehyde and 3-(2-furyl)prop-2-enal
}

El Mostapha Jouad, Magali Allain, Mustayeen A Khan, Gilles M Bouet

\section{To cite this version:}

El Mostapha Jouad, Magali Allain, Mustayeen A Khan, Gilles M Bouet. Structural and spectral studies of thiosemicarbazones derived from 3-furaldehyde and 3-(2-furyl)prop-2-enal. Journal of Molecular Structure, 2002, 604 (2-3), pp.205-209. 10.1016/S0022-2860(01)00650-0 . hal-03218045

\section{HAL Id: hal-03218045 \\ https://univ-angers.hal.science/hal-03218045}

Submitted on 6 May 2021

HAL is a multi-disciplinary open access archive for the deposit and dissemination of scientific research documents, whether they are published or not. The documents may come from teaching and research institutions in France or abroad, or from public or private research centers.
L'archive ouverte pluridisciplinaire HAL, est destinée au dépôt et à la diffusion de documents scientifiques de niveau recherche, publiés ou non, émanant des établissements d'enseignement et de recherche français ou étrangers, des laboratoires publics ou privés. 


\title{
Structural and spectral studies of thiosemicarbazones derived from 3-furaldehyde and 3-(2-furyl)prop-2-enal
}

\author{
El Mostapha Jouad ${ }^{\mathrm{a}}$, Magali Allain ${ }^{\mathrm{b}}$, Mustayeen A. Khan ${ }^{\mathrm{a}}$, Gilles M. Bouet ${ }^{\mathrm{a}, *}$ \\ ${ }^{\mathrm{a}}$ Faculté de Pharmacie, 16 Boulevard Daviers, 49045 Angers Cedex 01, France \\ ${ }^{\mathrm{b}}$ IMMO, UMR 6501 CNRS, Faculté des Sciences, 2 Boulevard Lavoisier, 49045 Angers Cedex, France
}

Received 22 February 2001; revised 15 May 2001; accepted 15 May 2001

\begin{abstract}
3-Furaldehyde thiosemicarbazone (3FTSC) and 3-(2-furyl)prop-2-enal thiosemicarbazone (FATSC) have been prepared, their structures solved and IR, ${ }^{1} \mathrm{H}$ NMR spectra recorded. The thiosemicarbazone moiety in both compounds shows an $E$ configuration about $\mathrm{C} 1-\mathrm{N} 2$ and $\mathrm{C} 2-\mathrm{N} 3$. Intramolecular and intermolecular hydrogen bondings occur in both the molecules. The angles between the mean planes of the furanic ring and thiosemicarbazone moiety present a significant difference in the two compounds. Moreover, the ${ }^{1} \mathrm{H}$ NMR and IR spectral studies of two compounds are quite similar. (C) 2002 Elsevier Science B.V. All rights reserved.
\end{abstract}

Keywords: Thiosemicarbazone; Crystal structure; 3-Furaldehyde; 3-(2-Furyl)prop-2-enal

\section{Introduction}

Thiosemicarbazone derivatives and their metallic complexes have extensive biological properties such as antitumoral [1-5], fungicidal [6,7], bactericidal [8] and antiviral [3] activity. As part of our continued research work on synthesis and biological activity, specially with thiosemicarbazones and semicarbazones of furaldehyde and their metal complexes, we report here the crystal structure of two new thiosemicarbazones derived from 3-furaldehyde (3FTSC) and 3-(2-furyl)prop-2-enal (FATSC). The chemical structures are shown in Fig. 1.

\footnotetext{
* Corresponding author. Tel.: +33-2-41226600; fax: +33-241486733.

E-mail address: gilles.bouet@univ-angers.fr (G.M. Bouet).
}

\section{Experimental}

\subsection{Synthesis}

The 3FTSC was synthesized by refluxing 3-furaldehyde and thiosemicarbazide (1:1 molar ratio) in absolute ethanol in the presence of acetic acid $\left(5 \mathrm{~cm}^{3}\right)$. The mixture was refluxed for $1 \mathrm{~h}$ and then cooled, filtered and recrystallized from a mixture of ethanol $(75 \%)$ and water. Yellow microcrystalline products are obtained. (Analysis results for $\mathrm{C}_{6} \mathrm{H}_{7} \mathrm{~N}_{3}$ OS: Found: C, 42.90; H, 4.19; N, 24.70. Calculated: C, 42.59; $\mathrm{H}, 4.17 ; \mathrm{N}, 24.83$.) $\mathrm{Mp} 154-155^{\circ} \mathrm{C}$.

FATSC was obtained after a $24 \mathrm{~h}$ contact of 3-(2furyl)prop-2-enal with thiosemicarbazide in a mixture of $20 \mathrm{~cm}^{3}$ of methanol and $30 \mathrm{~cm}^{3}$ of ethanol at room temperature. A yellow precipitate is formed, which is filtered, washed with ethanol and recrystallized in 
(a)<smiles>NC(=S)N/N=C/c1ccoc1</smiles>

(b)<smiles>NC(=S)N/N=C/C=C/c1ccco1</smiles>

Fig. 1. Chemical structures of 3FTSC (a) and FATSC (b).

ethanol solution with some water drops. Yellow microcrystalline products are obtained. (Analysis results for $\mathrm{C}_{8} \mathrm{H}_{9} \mathrm{~N}_{3} \mathrm{OS}$ : Found: $\mathrm{C}, 49.29 ; \mathrm{H}, 4.48 ; \mathrm{N}, 21.46$. Calculated: $\mathrm{C}, 49.21 ; \mathrm{H}, 4.65 ; \mathrm{N}, 21.52$.) $\mathrm{Mp} 157-158^{\circ} \mathrm{C}$.

\subsection{Physical measurements}

Elemental analysis were carried out by the Service Central d'Analyses (CNRS, Vernaison, France). Melting points were determined with a digital melting point apparatus using capillary technique. IR spectra were recorded with a Shimadzu FTIR-8010M spectrometer between 400 and $4600 \mathrm{~cm}^{-1}$ ( $\mathrm{KBr}$ disks). The ${ }^{1} \mathrm{H}$ NMR spectra were recorded on a Bruker Advance DRX500 in DMSO- $\mathrm{d}_{6}$ operating at $500 \mathrm{MHz}$. The chemical shifts, $\delta$, are given in parts per million (relative to TMS) and coupling constants in hertz.

\subsection{X-ray data collection, structure solution and refinement}

Yellow crystals of 3FTSC and FATSC were mounted on glass fibres and used for data collection.

Table 1

Crystal data and structure refinement for 3-furaldehyde and 3-(2-furyl)acrolein thiosemicarbazone, 3FTSC and FATSC, respectively

\begin{tabular}{|c|c|c|}
\hline Compound & 3FTSC & FATSC \\
\hline Empirical formula & $\mathrm{C}_{6} \mathrm{H}_{7} \mathrm{~N}_{3} \mathrm{OS}$ & $\mathrm{C}_{8} \mathrm{H}_{9} \mathrm{~N}_{3} \mathrm{OS}$ \\
\hline Color, habit & Yellow, switch needle & Yellow, plate \\
\hline Crystal size (mm) & $1.40 \times 0.14 \times 0.11$ & $0.34 \times 0.29 \times 0.11$ \\
\hline Crystal system & Monoclinic & Monoclinic \\
\hline Space group & $P 2_{1} / n$ & $P 2_{1} / c$ \\
\hline \multicolumn{3}{|l|}{ Unit cell dimensions } \\
\hline$a(\AA)$ & $10.792(5)$ & $13.305(3)$ \\
\hline$b(\AA)$ & $5.705(4)$ & $9.485(4)$ \\
\hline$c(\AA)$ & $13.821(7)$ & $7.501(3)$ \\
\hline$\beta\left(^{\circ}\right)$ & $109.29(2)$ & $88.66(5)$ \\
\hline Volume $\left(\AA^{3}\right)$ & $803(1)$ & $946(1)$ \\
\hline$Z$ & 4 & 4 \\
\hline Formula weight & 169.21 & 195.24 \\
\hline Density calculated $\left(\mathrm{g} / \mathrm{cm}^{3}\right)$ & 1.40 & 1.37 \\
\hline Diffractometer & Enraf Nonius MACH3 & Enraf Nonius MACH3 \\
\hline Radiation $(\lambda, \AA)$ & Mo K $\alpha(0.71073)$ & Mo K $\alpha(0.71073)$ \\
\hline Abs. coeff. $\left(\mathrm{mm}^{-1}\right)$ & 0.347 & 0.304 \\
\hline$F(000)$ & 352 & 408 \\
\hline$\theta$ range for data collected $\left(^{\circ}\right)$ & $11-16$ & $10-11.9$ \\
\hline \multirow[t]{3}{*}{ Index ranges } & $0 \leq h \leq 12$ & $-8 \leq h \leq 0$ \\
\hline & $0 \leq k \leq 6$ & $0 \leq k \leq 10$ \\
\hline & $-16 \leq l \leq 15$ & $-15 \leq l \leq 15$ \\
\hline Total reflections & 1651 & 1725 \\
\hline Unique reflections & 1566 & 1559 \\
\hline Observed reflections, $[I>$ & 1108 & 508 \\
\hline \multicolumn{3}{|l|}{$3 \sigma(I)]$} \\
\hline Final $R$ indices & $R_{1}=0.040 ; w R=0.053$ & $R_{1}=0.057 ; w R=0.073$ \\
\hline$R$ indices (all data) & $R_{1}=0.057 ; w R=0.056$ & $R_{1}=0.266 ; w R=0.201$ \\
\hline Goodness-of-fit & 1.141 & 1.311 \\
\hline Large diff. peak $(\mathrm{e} \AA)^{-3}$ & 0.305 & 0.267 \\
\hline
\end{tabular}


Table 2

Selected bond distances $(\AA)$ and angles $\left(^{\circ}\right)$ for 3FTSC and FATSC

\begin{tabular}{lrr}
\hline & \multicolumn{1}{l}{ 3FTSC } & FATSC \\
\hline Bond distance & & \\
S-C1 & $1.690(2)$ & $1.675(9)$ \\
O-C5 & $1.363(3)$ & $1.41(1)$ \\
O-C6 & $1.366(3)$ & \multicolumn{1}{l}{} \\
O-C8 & - & $1.33(1)$ \\
N1-C1 & $1.322(2)$ & $1.33(1)$ \\
N2-N3 & $1.386(2)$ & $1.37(1)$ \\
N2-C1 & $1.338(2)$ & $1.33(1)$ \\
N3-C2 & $1.271(2)$ & $1.27(1)$ \\
C2-C3 & $1.446(3)$ & $1.42(1)$ \\
C3-C4 & - & $1.34(1)$ \\
C4-C5 & - & $1.41(1)$ \\
& & \\
Bond angle & $120.4(1)$ & $121.4(7)$ \\
N3-N2-C1 & $115.2(2)$ & $117.8(7)$ \\
N2-N3-C2 & $123.6(1)$ & $122.0(7)$ \\
S-C1-N1 & $119.0(1)$ & $121.8(6)$ \\
S-C1-N2 & $117.4(2)$ & $116.2(8)$ \\
N1-C1-N2 & $121.3(2)$ & $121.2(8)$ \\
N3-C2-C3 & $129.4(2)$ & $124.4(8)$ \\
C2-C3-C4 & $124.9(2)$ & - \\
C2-C3-C6 & - & $126.5(8)$ \\
C3-C4-C5 & & \\
\hline
\end{tabular}

X-ray diffraction data were collected at $293 \mathrm{~K}$ on an Enraf Nonius MACH3 four-circle diffractometer $(\lambda \mathrm{Mo} \mathrm{K} \alpha=0.71073 \AA$ ) equipped with a graphite monochromator (IMMO, UMR 6501 CNRS). Cell constants and an orientation matrix for data collection were obtained by least-squares refinement of diffrac- tion data from 25 reflections. The two structures were solved by direct methods (SIR) using MolEN package programs [9] and $F$ was refined by a full-matrix leastsquares technique using anisotropic displacement parameters, except for $\mathrm{C}$ atoms in FATSC, which were refined using isotropic displacement parameters. The reason for this is that the small size of crystal is not sufficient in this case to obtain enough data (Table 1).

All hydrogen atoms in 3FTSC and those attached to nitrogen atoms in FATSC were located from Fourier difference synthesis and refined isotropically. The remaining hydrogen atoms in FATSC were located from the HYDRO program [9].

\section{Results and discussion}

Table 1 gives the crystal data collection, data reduction and structure refinement for 3FTSC and FATSC. The selected bond distances and angles are listed in Table 2. Intramolecular and intermolecular hydrogen bonding parameters are presented and the mean plane data are compiled in Table 3.

\subsection{Structural characterization}

The numbering scheme and a displacement ellipsoid plot of 3FTSC and FATSC are shown in Figs. 2 and 3, respectively. In the two compounds, the sulfur atom and the hydrazone nitrogen N3 are in trans position with respect to the $\mathrm{C} 1-\mathrm{N} 2$ bond,

Table 3

Intramolecular and intermolecular hydrogen bonding parameters, the mean planes, deviations from mean planes, and angles between mean planes for 3FTSC and FATSC

\begin{tabular}{llllll}
\hline Compound & $\mathrm{D}-\mathrm{H} \cdots \mathrm{A}$ & $d(\mathrm{D}-\mathrm{H})$ & $d(\mathrm{H} \cdots \mathrm{A})$ & $d(\mathrm{D} \cdots \mathrm{A})$ & \multicolumn{1}{c}{ (DHA) } \\
\hline 3FTSC & $\mathrm{N} 1-\mathrm{H} 2 \cdots \mathrm{N} 3$ & 0.902 & $2.203(7)$ & $2.648(2)$ & $104(2)$ \\
& $\mathrm{N} 1-\mathrm{H} 1 \cdots \mathrm{S}$ & 0.772 & $2.66(2)$ & $3.432(2)$ & $173.83(7)$ \\
& $\mathrm{N} 2-\mathrm{H} 3 \cdots \mathrm{S}$ & 0.897 & $2.51(2)$ & $2.64(1)$ & $167.97(7)$ \\
FATSC & $\mathrm{N} 1-\mathrm{H} 2 \cdots \mathrm{N} 3$ & 0.879 & $2.28(2)$ & $3.464(8)$ & $112.3(5)$ \\
& $\mathrm{N} 1-\mathrm{H} 1 \cdots \mathrm{S}$ & 0.915 & $2.649(3)$ & & Angle with previous plane \\
& & & & & $7.94(1)$ \\
3FTSC & $\mathrm{Clane}$ & Mean deviation & Largest deviation & & \\
& $\mathrm{C} 2-\mathrm{C} 2-\mathrm{C} 3-\mathrm{N} 2-\mathrm{O}-\mathrm{C} 1-\mathrm{N} 1-\mathrm{S}$ & 0.0043 & 0.0715 & 0.1203 & \\
FATSC & $\mathrm{C} 5-\mathrm{C} 6-\mathrm{C} 7-\mathrm{C} 8-\mathrm{O}$ & 0.0241 & 0.0357 & $22.6(1)$ \\
& $\mathrm{C} 2-\mathrm{N} 3-\mathrm{N} 2-\mathrm{C} 1-\mathrm{N} 1-\mathrm{S}$ & 0.1513 & 0.2720 &
\end{tabular}




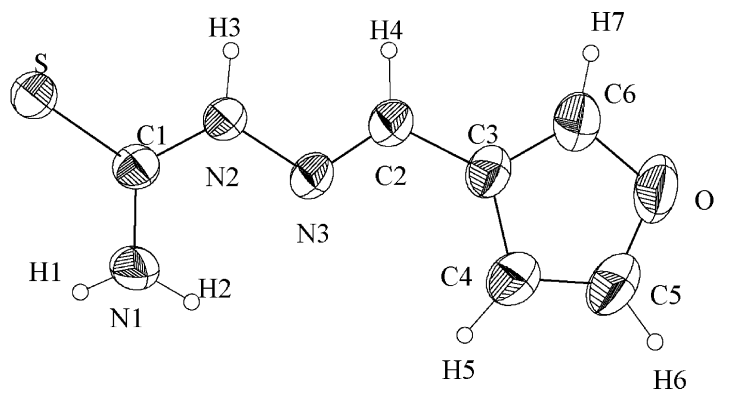

Fig. 2. Perspective view with atom numbering scheme and displacement ellipsoids at $50 \%$ probability level of 3FTSC.

and the molecular configuration is determined by the presence of the intramolecular hydrogen bond N1H2 $\cdots$ N3 (Table 3).

The two molecules also show a difference in planarity (Table 3). In FTSC, the thiosemicarbazone moiety (CSNN) and the furanic ring present a slight dihedral angle of $7.94(1)^{\circ}$, which gives a remarkable planarity to the whole molecule. This is not the case with FATSC because of the length of the side chain and the angle between the mean planes is $22.6(1)^{\circ}$.

The bond distances shown in Table 2 indicate that the $\mathrm{C}-\mathrm{S}$ bond length of 1.690(2) and 1.675(9) $\AA$ in 3 FTSC and FATSC, respectively, agree with similar bond in related compounds $[10,11]$. This distance is intermediate between that of single $\mathrm{C}-\mathrm{S}$ bond distance of $1.82 \AA$ and that of double $\mathrm{C}-\mathrm{S}$ bond $1.56 \AA$ [12]. Consequently, the $\mathrm{C}-\mathrm{S}$ bond in these thiosemicarbazones possesses only partial doublebond character. This hypothesis is supported by the bond distances around $\mathrm{C}(1)$, which is 1.322(2) and $1.338(3) \AA$ for $\mathrm{N}(1)$ and $\mathrm{N}(2)$, respectively, in
3FTSC. As regards FATSC, the corresponding distances are 1.33(1) $\AA$ for both of them. These values are indicative of partial double-bond character.

A comparison of the $\mathrm{N}(2)-\mathrm{N}(3)$ distance of 1.386(2) $\AA$ for 3FTSC and 1.37(1) $\AA$ for FATSC with the corresponding $\mathrm{N}-\mathrm{N}$ distance of 1.411(2) $\AA$ for unsubstituted [13], 1.395(2) and 1.431(6) $\AA$ for 1-phenyl [14] and 4-phenyl [15] thiosemicarbazide, respectively, suggests that the $\mathrm{N}-\mathrm{N}$ bond also has some double-bond character. A similar shortening of the $\mathrm{N}-\mathrm{N}$ bond, with an average value of $1.37 \AA$, was observed in thiosemicarbazones having a extensively delocalized group on the nitrogen $\mathrm{N}(3)$ [16,17]. This delocalization is shown by the furanic ring in the case of 3FTSC whereas in FATSC it is the conjugation of the $\pi$ bond in the side chain, which leads to the same phenomenon.

In both compounds, the three hydrogens attached to $\mathrm{N} 1$ and $\mathrm{N} 2$ atoms have the potential to form donor hydrogen bonds. In 3FTSC, the intermolecular hydrogen bonds link the molecules together in the solid state and they are $\mathrm{N} 2-\mathrm{H} 3 \cdots \mathrm{S}(0.5-x,-0.5+$ $y, 0.5-z)$ and $\mathrm{N} 1-\mathrm{H} 1 \cdots \mathrm{S}(1.5-x, 0.5+y, 1.5-z)$ hydrogen bonds. On the other hand, the molecules of FATSC form a zig-zag chain parallel to the $b$-axis in the most common setting. The packing is governed by interaction-type hydrogen bonds, viz., $\mathrm{N} 1-\mathrm{H} 1 \cdots \mathrm{S}$ $(0.5-x, 1+y, 1+z)$. Separations of all these hydrogen bonds (Table 3) agrees well with that in most thiosemicarbazones $[18,19]$.

\subsection{Spectral studies}

The ${ }^{1} \mathrm{H}$ NMR spectrum of compound 3FTSC shows

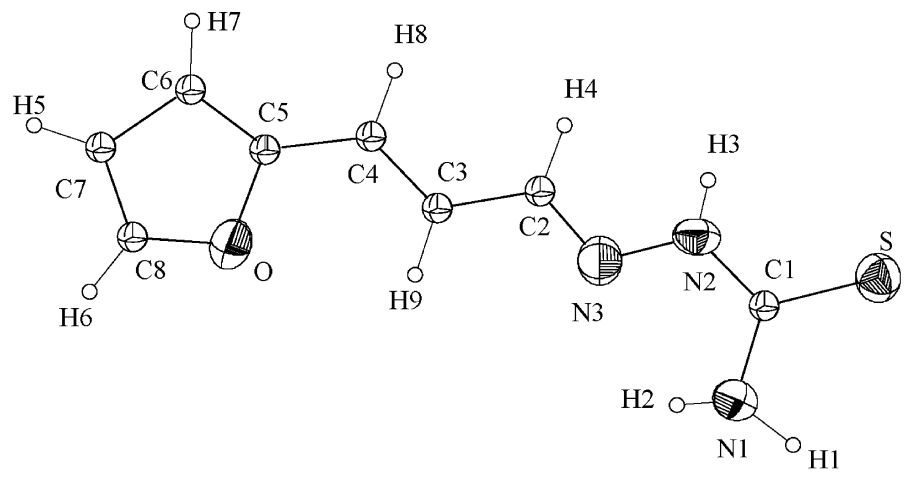

Fig. 3. Perspective view with atom numbering scheme and displacement ellipsoids at $50 \%$ probability level of FATSC. 
Table 4

Main IR spectral vibrations $\left(\mathrm{cm}^{-1}\right)$ for 3 FTSC and FATSC, a: antisymmetric, s: symmetric, (s): strong, (m): medium, (w): weak

\begin{tabular}{lll}
\hline & 3 FTSC & FATSC \\
\hline$\nu\left(\mathrm{NH}_{2}\right)$ & $3434 \mathrm{a}(\mathrm{s})$ & $3421 \mathrm{a}(\mathrm{s})$ \\
$\nu(\mathrm{NH})$ & $3252 \mathrm{~s}(\mathrm{~m})$ & $3262 \mathrm{~s}(\mathrm{w})$ \\
$\nu(\mathrm{C}=\mathrm{S})$ & $3309(\mathrm{~m})$ & $3148(\mathrm{~m})$ \\
& $1362(\mathrm{w})$ & $1352(\mathrm{w})$ \\
$\nu(\mathrm{C}=\mathrm{N})$ & $765(\mathrm{~m})$ & $748(\mathrm{~m})$ \\
$\delta(\mathrm{C}-\mathrm{O}-\mathrm{C})$ & $1584(\mathrm{~s})$ & $1597(\mathrm{~m})$ \\
$\nu(\mathrm{C}-\mathrm{N})$ & $1290(\mathrm{~m})$ & $1272(\mathrm{~m})$ \\
$\nu(\mathrm{N}-\mathrm{N})$ & $1153(\mathrm{w})$ & $1096(\mathrm{w})$ \\
Ring breathing & $936(\mathrm{~m})$ & $923(\mathrm{~m})$ \\
\hline
\end{tabular}

a singular peak at $13.37 \mathrm{ppm}$ relative to the $\mathrm{H} 3$ while the signal of the proton on the $\mathrm{H} 4$ double bond appears at $8.10 \mathrm{ppm}$. It is interesting to note the presence of two broad singulets for $\mathrm{H} 1$ and $\mathrm{H} 2$ protons at 8.16 and $7.99 \mathrm{ppm}$, which means that the free rotation around the $\mathrm{C}-\mathrm{N}$ bond is blocked because of its partial doublebond character [17]. As regards FATSC, ${ }^{1} \mathrm{H}$ NMR analysis shows that it has a signal identical with 3FTSC, in the same range with a massive between 6.91 and $6.54 \mathrm{ppm}$, which corresponds to the chemical shift of $\mathrm{H} 5, \mathrm{H} 7$ and $\mathrm{H} 9$ protons.

The main IR data are given in Table 4 and it can be seen that the infrared spectra of the two compounds are quite similar. The spectroscopical data agree with the structural results.

The bands appearing around 1355 and $752 \mathrm{~cm}^{-1}$ are assigned to $\nu(\mathrm{C}=\mathrm{S})$ vibration $[11,20]$. The bands in the region $3270-3440 \mathrm{~cm}^{-1}$ are attributed to symmetrical and asymmetrical stretching modes $\nu\left(\mathrm{NH}_{2}\right)$ [21]. On the other hand, the strong band observed at $1600 \mathrm{~cm}^{-1}$ is assigned to $\nu(\mathrm{C}=\mathrm{N})$ frequencies [11,21].

\section{Supplementary material}

Crystallographic data for $\mathrm{C}_{6} \mathrm{H}_{7} \mathrm{~N}_{3} \mathrm{OS}$ (3FTSC), CCDC \#157882 and $\mathrm{C}_{9} \mathrm{H}_{8} \mathrm{~N}_{3} \mathrm{OS}$ (FATSC), CCDC \#157883 have been deposited with the Cambridge Crystallographic Data Centre as supplementary publication no. CCDC-1003/m. Copies of available material can be obtained, free of charge, on applica- tion to CCDC, 12 Union Road, Cambridge CB2 1EZ, UK (fax: +44-1223-336033 or e-mail: deposit@ccdc.cam.ac.uk).

\section{References}

[1] Y. Kang, N. Yang, S.O. Kang, J. Ko, C.H. Lee, Y.H. Lee, Organometallics 16 (1997) 5522.

[2] D.X. West, J.K. Swearingen, J. Valdés-Martínez, S. Hernández-Ortega, A.K. El-Sawaf, F.V. Meurs, A. Castiñeiras, I. Garcia, E. Bermejo, Polyhedron 18 (1999) 2919.

[3] P. Tarasconi, S. Capacchi, G. Pelosi, M. Cornia, R. Albertini, A. Bonati, P.P. Dall'Aglio, P. Lunghi, S. Pinelli, Bioorg. Med. Chem. 8 (2000) 157.

[4] A. Kumar, U. Chandra, S. Chandra, Synth. React. Inorg. MetOrg. Chem. 23 (4) (1993) 671.

[5] L.J. Ackerman, P.E. Fanwick, M.A. Green, E. John, W.E. Running, J.K. Swearingen, J.W. Webb, D.X. West, Polyhedron 18 (1999) 2759.

[6] S.G. Teoh, S.H. Ang, H.K. Fun, C.W. Ong, J. Organomet. Chem. 580 (1999) 17.

[7] E. Bermejo, R. Carballo, A. Castiñeiras, R. Dominguez, C. Maichle-Mössmer, J. Strähhle, D.X. West, Polyhedron 18 (1999) 3695.

[8] S. Abram, C. Maichle-Mössmer, U. Abram, Polyhedron 17 (1998) 131.

[9] Crystal Structure Analysis, Molecular Enraf-Nonius (MolEN), Delft Instruments X-ray Diffraction, Delft, The Netherlands, 1990.

[10] S.C. Bhatia, P. Gautam, A.K. Chatrath, P.C. Jain, Ind. J. Chem., Sect. B 32 (1993) 1237.

[11] E.M. Jouad, A. Riou, M. Allain, M.A. Khan, G.M. Bouet, Polyhedron 20 (2001) 67.

[12] L.E. Sutton, Table of interatomic distances and configurations, Molecules and Ions, The Chemical Society, London, 1965.

[13] G.D. Andretti, P. Domino, G. Fava, M. Nardelli, P. Sgarbotto, Acta Crystallogr., Sect. B 26 (1970) 1005.

[14] M. Czulger, A. Kalman, G. Argay, Cryst. Struct. Commun. 2 (1973) 655.

[15] A. Kalman, G. Argay, M. Czulger, Cryst. Struct. Commun. 1 (1972) 375.

[16] G.J. Palenik, D.F. Rendle, W.S. Carter, Acta Crystallogr., Sect. B 30 (1974) 2390.

[17] Y. Tian, C. Duan, C. Zhao, X. You, Inorg. Chem. 36 (1997) 1247.

[18] H. Beraldo, R. Lima, L.R. Teixeira, A.A. Moura, D.X. West, J. Mol. Struct. 553 (2000) 43.

[19] I.C. Mendes, L.R. Teixeira, R. Lima, H. Beraldo, N.L. Spaziali, D.X. West, J. Mol. Struct. 559 (2001) 355.

[20] L. Lima, L.R. Teixeira, T.G. Carneiro, H. Beraldo, J. Braz. Chem. Soc. 10 (1999) 184.

[21] P. Bindu, M.P. Kurup, T. Satyakeerty, Polyhedron 18 (1999) 321. 